\title{
Testing for Convergence in the European Insurance Sector: A Non-Linear Factor Approach
}

\author{
Dr. Nicholas Apergis* \\ University of Piraeus, 185 34, Greece \\ E-mail: napergis@unii.gr \\ Dr. Alexandros Gabrielsen \\ Sumitomo Mitsui Banking Corporation Europe, London, UK \\ E-mail: alexandros_gabrielsen@gb.smbcgroup.com \\ Dr. James Payne \\ University of South Florida, 4202 E. Fowler Avenue, Tampa, FL 33620, USA \\ E-mail: jpayne@poly.usf.edu \\ Dr. Paolo Zagaglia \\ Università di Bologna, Strada Maggiore 45 - 40126, Italy \\ E-mail: pzagaglia@bologna.it
}

Received: May 3, 2012 Accepted: May 25, 2012 Published: December 1, 2012

doi:10.5296/ajfa.v4i2.1764 URL: http://dx.doi.org/10.5296/ajfa.v4i2.1764

The views expressed in this paper solely reflect the views of the author and not necessarily those of Sumitomo Mitsui Banking Corporation Europe Limited.

\begin{abstract}
This paper investigates the factors behind long-term convergence in the insurance sector by questioning the role of harmonization and regulation across the EMU. By investigating convergence through balance-sheet items, the study sheds light on the role played by the
\end{abstract}




\section{Macrothink}

Asian Journal of Finance \& Accounting ISSN 1946-052X 2012, Vol. 4, No. 2

management preferences of insurances across the EMU. Overall, the convergence tests employed within this study provide evidence of limited convergence within the insurance sector across the EMU countries.

Keywords: financial convergence, Phillip and Sul convergence method, European insurance sector

\footnotetext{
* Corresponding author
} 


\section{Introduction - Literature Review}

Over the recent period, the financial services industry has experienced significant convergence trends, mainly due to the deregulation of financial markets in Europe, the U.S., and Asia. Prior to the introduction of the European Monetary Union (EMU), the European markets were a fragmented network due to the heterogeneous taxation, regulatory and transaction costs regimes, increasing the complexity of cross-market development. Therefore, expectations to find convergence are based on the effects of the harmonization of regulatory and supervisory policies as well as the mechanisms for coordination of macroeconomic policies of the national authorities with the EMU. Although under the notion of optimum currency, all factors of production should move freely across borders, it is capital flows that cross borders much more easily than labor or goods. Hence, financial markets are expected to show a faster rate of convergence compared to the other markets. There are still open questions regarding insurance integration within the EMU which are not attributable to labor heterogeneity or persistent residual regulatory differences between member states but also to the effects of the recent credit crisis on the overall European insurance sector.

Convergence in the market for risk transfer within the property-liability insurance industry has been rather slow, due to certain factors as informational opacity of insurance markets, informational asymmetries between buyers and insurers and between insurers and reinsurers, high transactions costs, and, finally, inhibiting financial innovations that require transparency. Nevertheless, convergence in the property-liability insurance market is strong with the most important driver of such trend being the growth in property values in geographical areas prone to catastrophic risk, the capacity of the convergence process itself to moderate the effects of the reinsurance underwriting cycle, the advances of computing and communicating technologies, the development of holistic or enterprise-wide risk management, the presence of certain regulatory, accounting, tax, and rating agency factors enabling insurers to develop a wide range of products to control regulatory and tax costs, and, finally, developments in financial theories that provided a clear understanding to market participants about risk management approaches and financial innovation opportunities (Cummins et al., 2004; Cummins, 2005; Cummins and Weiss, 2009).

Critical questions extend on how to measure the degree of financial integration and ultimately convergence within the insurance sector. Growth theory was the main motivator behind economic convergence with the notional idea that the rate of increase of per capita output is inversely related to the initial level of this variable. This is referred to as absolute convergence and the economic interpretation is that if all economies have the same steady state and differ only with respect to initial conditions, then emerging or less developed economies will grow at a faster rate and will eventually catch up with the developed economies. Barro and Sala-i-Martin $(1991,1992)$ introduce the concepts of $\beta$ - and $\sigma$-convergence based on the log-linearized approximation of the Solow growth model with a Cobb-Douglas production function. The $\beta$-convergence determines the speed of adjustment of deviations to the long-run equilibrium whereas $\sigma$-convergence determines the decline in the variance in the overall cross-section dispersion. 
The initial idea of convergence has been extended and applied to a wide range of financial problems, among which is financial market integration. Baele et al. (2004) defines financial integration as the market for a given financial instrument when all economic agents with the same relevant characteristics that act in the market face a single set of rules, have equal access and are treated equally. There is a well developed literature that tries to test and find evidence of financial integration. The studies of Adam et al. (1998), Baele et al. (2004), Ozcan et al. (2009), Lane, (2008), Fabozzi and Choudhry, (2004), Hristov and Rozenov (2009) measure the evolution of capital market integration in the European Union (EU) in terms of a set of financial indicators such as: price-based measures that capture the discrepancies in asset prices across different European markets; news-based response measures that analyze the impact of common factors on assets; quantity-based measures that quantify the effects of frictions on the demand for and supply of securities. They find that although integration varies across different product segments and different periods, it has been achieved at a substantial level between standardised fixed income and money markets, i.e. unsecured inter-bank deposits such as EONIA and EURIBOR, and interest rate swaps.

Along with the $\beta$ - and $\sigma$-convergence measures, which are based on cross-sectional data, there are a number of studies which employ time series tests of convergence. Affinito and Farabullini (2006) apply the law of one price to investigate the integration of the EU retail banking. Datta (2003) proposes a transitional dynamics and convergence in a time-series framework. Sorensen and Guiterez (2006) apply cluster analysis techniques to detect possible patterns and trends in the Euro area banking sector in terms of the degree of homogeneity of counties. Hardouvelis et al $(2004,2007)$ apply the Bekaert and Harvey $(1995,1997)$ time-varying integration model to measure the integration of EMU economic and monetary integration. Ferreira and Gama (2005) apply a volatility decomposition method to study the volatility dynamics at the world, country and local industry levels. Fratzscher (2002) measures financial integration based on an uncovered interest rate parity condition. They all find that the integration of the retail banking sector is still progressing, while Sorensen and Guiterez (2006) identify the presence of clusters within the EMU: the contains Germany, France, Belgium Netherland, Austria and Italy and the second Spain, Portugal and Greece.

However, a number of shortcomings have been identified in the application of these tests outside the growth context since $\beta$ - and $\sigma$-convergence tests are uninformative on the behavior of the individual economies within the entire cross-sectional panel as well as restrictive in their assumptions regarding the underlying panel structures (Islam, 2003; Friedman, 1992; Quah, 1996; among others).

Phillips and Sul (2007) propose a non-linear time varying factor representation that overcomes the restrictions of unit root and cointegration tests. Their formulation allows the estimation of long-run equilibria within a heterogeneous panel, a wide variety of possible transition paths towards convergence relative to the panel cross section average over time and the identification of the presence of club formation. The Phillips and Sul (2007) formulation is a very robust and attractive informative measure on the behavior of dynamic characteristics of the heterogeneous panel. Fritsche and Kuzin (2008) apply this method to investigate convergence in European prices, unit labor costs, income and productivity over the period 
1960-2006 and find different transition paths of convergence as well as regional clusters. Caporale et al. (2009) apply the Phillips and Sul (2007) method to test for convergence in stock returns to an extensive dataset including monthly stock prices for five EU countries as well as the US over the period from 1973 to 2008. They are able to document convergence/divergence patterns as well as to detect clusters on a sectoral, industry and global level. They also find that there is a global convergence/divergence process which is not influenced by EU developments, but argue that it may be driven by industry versus country effects. Rughoo and Sarantis (2009) apply the Phillips and Sul (2007) framework to investigate the integration process in the EU retail banking sector during the period from 1995 to 2008 by analysing deposit and lending rates to non-financial corporations.

These results highlight the limited convergence achieved by European institutions particularly in the banking sector due to persistent regulatory and cross-country heterogeneity, accompanied by the effects of the recent credit crisis on macro fundamentals, i.e. expectations of inflation, growth rates, sovereign credit risk, among others, to liquidity and credit risk in the banking and insurance sectors. Following the EU sovereign debt crisis, there have been a number of key developments to reform the functioning of the EMU in the event of a crisis. This led to the creation of the European Stability Facility (EFSF), the European Financial Stability Mechanism (EFSM) and European Treasury. The first two are legal instruments aiming at preserving the financial stability in EMU by providing financial assistance to EMU states in difficulty. The European Treasury is an authority that is responsible for tax policy oversight and government spending coordination of EU member countries.

For policy makers financial integration poses a number of challenges that we try to address in this study. Therefore, the goal of this study is to investigate the effects of the recent crisis as well as the harmonisation measures put forward on the integration of the EU insurance sector. In this respect we apply the Phillips and Sul (2007) convergence formulation and clustering algorithm. In particular, the study employs a sample of 16 insurance companies within the EMU and it bases the analysis on balance sheet management. Not only has this approach not been previously applied, but it is a reflection of the institutions' long-term strategic management with responses to the exogenous macro conditions. This research effort will provide useful insights into the integration dynamics of the sector under study. The results will allow policy makers to visualise which country's insurances will converge and, thus, adopt specific measures to promote a higher degree of integration for the other countries' insurances.

The paper is organised as follows: Section 2 outlines the methodology employed in this study, while section 3 describes the data set. Section 4 presents the empirical results and section 5 concludes.

\section{Methodology}

Take the simple example of a single factor model:

$$
X_{i t}=\delta_{i} \mu_{t}+\varepsilon_{i t}
$$




\section{Macrothink}

where $\delta_{i}$ measures the idiosyncratic distance between some common factor $\mu_{t}$ and the systematic part of $X_{i t}$. The model captures the evolution of the individual $X_{i t}$ in relation to $\mu_{t}$ by means of its two idiosyncratic elements: the systematic element $\left(\delta_{i}\right)$ and the error $\left(\varepsilon_{i t}\right)$. Phillips and Sul (2007) extent (1) to allow the systematic idiosyncratic element to evolve over time; which accommodates heterogeneous agent behaviour and evolution in that behaviour by means of a time varying factor loading coefficient $\delta_{i t}$, such that:

$$
X_{i t}=\delta_{i t} \mu_{t}
$$

where both components are now time-varying and it is possible to use a non-parametric formulation to estimate a transition function based on $\delta_{i t}$; whish is given as:

$$
h_{i t}=\frac{X_{i t}}{\frac{1}{N} \sum X_{i t}}=\frac{\delta_{i t}}{\frac{1}{N} \sum \delta_{i t}}
$$

where $h_{i t}$ measures the loading coefficient $\delta_{i t}$ in relation to the panel average at time t. In case the factor loading coefficients $\delta_{i t}$ converge to $\delta$ then the relative transition parameters $h_{i t}$ converge to unity and the long run cross section variance of $h_{i t}$ to zero.

Measuring convergence entails the estimation of a regression t-test of the null hypothesis of convergence against the alternative of divergence:

$$
\begin{array}{llll}
H_{0}: & \delta_{i}=\delta & \text { and } & a \geq 0 \\
H_{1}: & \delta_{i} \neq \delta & \text { and } & a<0
\end{array}
$$

The regression of the cross sectional variance ratio $H_{1} / H_{t}$ is then given as:

$$
\log \left(\frac{H_{1}}{H_{t}}\right)-2 \log L(t)=\widehat{a}+\widehat{b} \log t+\widehat{u}_{t}, \quad t=[r T], \ldots[r T]+1, \ldots, T, \quad r>0
$$

where 


$$
\begin{aligned}
& H_{1}=\frac{1}{n} \sum_{i=1}^{N}\left(h_{i t}-1\right)^{2}, \\
& L(t)=\log (t+1)
\end{aligned}
$$

Additionally, the fitted coefficient of $\log t$ (i.e. speed of conversion) is given by $\hat{b}=2 \widehat{a}$, where $\hat{a}$ is the estimate of $\alpha$ in $H_{0}$; and the regression coefficient $\hat{b}$ is then tested under the one-sided null hypothesis $a \geq 0$ using a HAC standard error. Under convergence $\log \left(H_{1} / H_{t}\right)$ diverges to $\infty$, either as $2 \log L(t)$ when $\alpha=0$, or as $2 \alpha \log t$ when $a>0$. Divergence of $\log \left(H_{1} / H_{t}\right)$ corresponds to $H_{t} \rightarrow 0$ as $t \rightarrow \infty$.

Rejection of the null of convergence does not immediately imply that there is no evidence of convergence in the subgroups of the panel. It is possible, when moving away from the strict null hypothesis of full convergence, to observe convergence clusters around separate equilibrium, or even convergence clusters and divergent members in the full panel. It is, therefore, of paramount importance to identify these clusters. Phillips and Sul (2007) propose a clustering algorithm; which allows the investigation of possible relationships between the empirical clusters and economic characteristics. There are four steps describe the procedure to determine the clustering pattern and to provide a stopping rule for the calculations. The first step, orders the individuals in the panel according to the last observation in the panel; the second step; is to find a core convergence group based on a set of criteria and then proceed to, step three, to evaluate additional individuals for membership of this group. The final step provides the stopping rule for the cluster calculations.

\section{Data Description}

The study makes use of annual data for a number of financial ratios for 16 insurance institutions (due to data availability) spanning the period 1990-2010 obtained from Bloomberg. The names of the insurance institutions are presented in Table 1. The dataset includes not only global reinsurance institutions but also regional insurance institutions, a fact that allows the presence of adequate heterogeneity. Empirical evidence suggests that financial accounting ratios can predict future stock returns, especially in long horizons (Rozeff, 1984; Fama and French, 1988; Pontiff and Schall, 1998; Campbell and Shiller, 1988, 1989, 2005; Cochrane, 1992, 2008; Goetzman and Jorion, 1993; Hodrick, 1992; Lewellen, 2004; Lettau and Ludvigson, 2005; Hecht and Vuolteenaho, 2006; Lettau and Nieuwerburgh, 2008; among others). 
Table 1. List of insurance firms

\begin{tabular}{|lrr|lr|lr}
\hline UNIQA, VIENNA & \multicolumn{2}{|l|}{ INSURANCE, } & WUERTTEMBERGISCHE LE, & MUNCHENER & RUCKVEWR, \\
AGEAS, ALM & BRAND & AS, & ALLIANZ SE, GENERALI & NUERNBERGER & BET.-AG, \\
TOPDANMARK & A/S, & CNP & DEUTCH, & HANNOVER & SAMPO OYJ, MANNHEIMER \\
ASSURANCES, AXA, SCOR SE, & & RUECKVERSIC & & AG HOLDIN & \\
\end{tabular}

The accounting rations employed in this study are indicators such as, gross profits to assets, net (operating) income to assets, investment (net investment income before taxes) to assets, equity to assets, provisions of assets (assets which are held to cover obligations to policyholders), growth rates of total assets, total expenses to assets and total reserves to assets, that reflect various aspects of the insurance sector potential future course, such as, profitability, risk exposure, solvency, as well as operational, financial and strategic management.

\section{Empirical Findings}

The magnitude of the convergence coefficient, $\hat{b}$, delineates the speed of convergence; with

a typically a higher value, $\hat{b}$, indicating a faster rate of convergence. The Phillips and Sul (2007) $\log$ t-test results indicates rejection of the null hypothesis of convergence at the $5 \%$ significance level; illustrating that the EU insurance sector is heterogeneous in terms of strategic development as well as risk and financial management. Furthermore, the value of the convergence coefficient highlights the rate of divergence. In particular, regarding the insurance sector, the highest divergence reported for the insurance sector is detected for the investment to assets $\operatorname{ratio}(\widehat{b}=-1.564)$, followed by the growth rate of real total assets $(\widehat{b}=-1.121)$, with the lowest being detected for gross profits to assets ratio $(\widehat{b}=-0.433)$.

Overall, the log t-test provides evidence of limited convergence within the insurance sectors across the EMU countries. It is worth mentioning at this point that one of the advantages of the methodological approach is that the number of elements entering each sub-group could be ranged from one to infinity. In other words, even a single element, e.g. firm, is possible to form an entire sub-group without this altering the validity of the results. At the same time, any potential changes that could have occurred over the time span of our sample has been taken explicitly into consideration by the algorithm itself, since it is based on a non-linear function type of estimation.

Under the assumption that the optimizing behavior of insurances is exogenous and that it does not change through time, our results would be a mere reflection of convergence in both the real economies and across financial markets. However, insurance businesses are characterized by management preferences that tend to change as a function of the state of the 
economy, and of the conditions prevailing in financial markets. For instance, when funding conditions tighten in the markets, financial firms may change their asset-liability management plans accordingly. We can think of the short-term response to changes in aggregate macroeconomic and financial conditions as a manifestation of the tactical implementation of actions for the objective of profit maximization. The implementation of these types of actions can lead to a divergence in management practices. Financial firms also operate with the purpose of maximizing their company growth and profitability in the long run. In this context, they formulate strategic plans that lay down the general framework for tactical actions. Long-term plans are based on assumptions about the macroeconomic and financial environment that firms might see to prevail in the future. To sum up, by investigating convergence through balance-sheet items, our study sheds light on the role played by the management preferences of insurances across the EMU.

For the insurance section and with regards to Gross Profits to Assets two sub-clubs have been identified each with 14 and 2 insurers, respectively (Table 2). The first cluster consist of Uniqa, Vienna Insurance, Ageas, Alm Brand, TopDanmark, CNP Assurances, AXA, Scor, Wuerttembergische, Allianz, Generalli Deutsch, Hannover Rueckversic, Munchener Ruckver and Nuernberger Ber; and the second cluster of Sampo Oyj and Mannheimer. According to the algorithm of Phillips and Sul (2007), the methodology first selects UNIQA and Vienna Insurance and determines whether they converge in terms of their gross profits to assets ratio. Next, it compares these two as one with the Ageas. If the t-statistic recomme3nds convergence it adds the insurance firm in the same group, otherwise it forms a separate group, and so on. Moreover, according to the log t-test results the convergence is stronger for the second cluster.

Table 2. Gross profits to assets

\begin{tabular}{|l|l|l|l|}
\hline & Firms & b coefficient & t-statistic \\
\hline Full sample & \multicolumn{1}{|l}{ stub } & -0.433 & -2.843 \\
\hline $\mathbf{1}^{\text {st }}$ club & UNIQA, VIENNA INSURANCE, AGEAS, ALM & -0.513 & -1.495 \\
& BRAND AS, TOPDANMARK A/S, CNP ASSURANCES, & & \\
& AXA, SCOR SE, WUERTTEMBERGISCHE LE, & & \\
& ALLIANZ SE, GENERALI DEUTSCH, HANNOVER & & \\
& RUECKVERSIC, MUNCHENER RUCKVER, & & \\
& NUERNBERGER BET.-AG & & \\
\hline $\mathbf{2}^{\text {nd }} \mathbf{c l u b}$ & SAMPO OYJ, MANNHEIMER AG HOLDIN & 0.475 & 3.172 \\
\hline
\end{tabular}

There exist two sub-clubs within the Investment to Assets panel (Table 3); with 8 and 6 insurers, respectively. The first comprises of Uniqa, Ageas, TopDanmark, Scor, Hannover Rueckversic, Munchener Ruckver which appears to converge with a stronger convergence speed of $(\widehat{b}=0.358)$ than the second cluster $(\widehat{b}=-1.049)$; which is made up by the Alm 
Brand, AXA, Wuerttembergische, Generalli Deutsch, Mannheimer and Nuernberger Ber. The non-converging club is made by Vienna Insurance, Sampo Oyj and CNP Assurances. The club clustering algorithm also identifies three divergent insurers, namely Vienna Insurance, Sampo Oyj and CNP Assurances.

Table 3. Investment to assets

\begin{tabular}{|l|l|l|l|}
\hline & Firms & b coefficient & t-statistic \\
\hline Full sample & \multicolumn{1}{|l}{. } & -1.564 & -6.523 \\
\hline \multirow{4}{*}{$\mathbf{1}^{\text {st }} \mathbf{c l u b}$} & $\begin{array}{l}\text { UNIQA,AGEAS, TOPDANMARK A/S, SCOR SE, } \\
\text { ALLIANZ SE, HANNOVER RUECKVERSIC, } \\
\text { MUNCHENER RUCKVER }\end{array}$ & 0.358 & 3.469 \\
\hline \multirow{2}{*}{$\mathbf{2}^{\text {nd }} \mathbf{c l u b}$} & $\begin{array}{l}\text { ALM BRAND AS, AXA, WUERTTEMBERGISCHE LE, } \\
\text { GENERALI DEUTSCH, MANNHEIMER AG HOLDIN, } \\
\text { NUERNBERGER BET.-AG -1.049 }\end{array}$ & -1.395 \\
\hline $\begin{array}{l}\text { Non } \\
\text { converging }\end{array}$ & $\begin{array}{l}\text { VIENNA INSURANCE, SAMPO OYJ, CNP } \\
\text { ASSURANCES }\end{array}$ & -1.909 & -6.532 \\
\hline
\end{tabular}

Net Income to Assets is described by two sub-clubs with 3 and 4 (Table 4). The speed of convergence is higher for the second $\operatorname{club}(\widehat{b}=1.269)$, which consists of Sampo Oyj, Generalli Deutsch, Manheiimer, Nuernberger Bet; compared with the first club $(\widehat{b}=0.655)$ which is composed by Vienna Insurance, Alm Brand and Wuerttembergische. Finally, the Uniqa, Ageas, TopDanmark, CNP Assurances, AXA, Scor, Allianz, Hannover Rueckversic and Munchener Ruckver diverge according to the log t-test result.

Table 4. Net income to assets

\begin{tabular}{|c|c|c|c|}
\hline & Firms & b coefficient & t-statistic \\
\hline Full sample & & -1.046 & -19.134 \\
\hline $1^{\text {st }}$ club & $\begin{array}{l}\text { VIENNA INSURANCE, ALM BRAND AS, } \\
\text { WUERTTEMBERGISCHE LE }\end{array}$ & 0.270 & 0.655 \\
\hline $2^{\text {nd }}$ club & $\begin{array}{l}\text { SAMPO OYJ, GENERALI DEUTSCH, } \\
\text { MANNHEIMER AG HOLDIN, NUERNBERGER BET.-AG }\end{array}$ & 0.610 & 1.269 \\
\hline $\begin{array}{l}\text { Non } \\
\text { converging }\end{array}$ & $\begin{array}{l}\text { UNIQA, AGEAS, TOPDANMARK A/S, CNP } \\
\text { ASSURANCES, AXA, SCOR SE, ALLIANZ SE, } \\
\text { HANNOVER RUECKVERSIC, MUNCHENER RUCKVER }\end{array}$ & -0.651 & -37.447 \\
\hline
\end{tabular}


With regards to Equity to Assets there exist only one sub club that comprises of Vienna Insurance, ALM Brand, Sampo Oyj, Wuerttembergische, Generalli Deutsch, Mannheimer and Nuernberger Bet and all the reaming insurers according to the log t-test diverge (Table $5)$.

Table 5. Equity to assets

\begin{tabular}{|c|c|c|c|}
\hline & Firms & b coefficient & t-statistic \\
\hline Full sample & & -0.816 & -8.765 \\
\hline $1^{\text {st }}$ club & 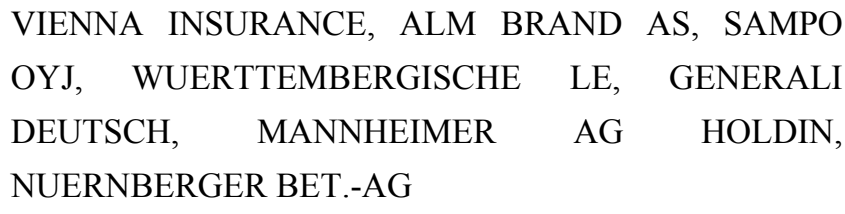 & 0.676 & 3.242 \\
\hline $\begin{array}{l}\text { Non-convergi } \\
\text { ng }\end{array}$ & $\begin{array}{l}\text { UNIQA, AGEAS, TOPDANMARK } \text { A/S, CNP } \\
\text { ASSURANCES, AXA, SCOR SE, ALLIANZ SE, } \\
\text { HANNOVER } \\
\text { RUCKVER }\end{array}$ & -0.803 & -45.190 \\
\hline
\end{tabular}

Under Provisions to Assets there are two sub-groups (Table 6). The second club converges at higher speed $(\widehat{b}=1.746)$ than the first club $(\widehat{b}=0.091)$. The first club is made up by Vienna Insurance, ALM Brand, AXA, Wuerttembergische, Mannheimer and Nuernberger Bet; while the second by Sampo Oyj and Generali Deutsh. Finally, the club converging algorithm reveals that Uniqa, Ageas, TopDanmark, CNP Assurances, Scor, Allianz, Hannover Rueckversic and Munchener Ruckver diverge.

Table 6. Provisions to assets

\begin{tabular}{|c|c|c|c|}
\hline & Firms & b coefficient & t-statistic \\
\hline Full sample & & -0.542 & -4.672 \\
\hline $1^{\text {st }}$ club & $\begin{array}{l}\text { VIENNA INSURANCE, ALM BRAND AS, AXA, } \\
\text { WUERTTEMBERGISCHE LE, MANNHEIMER AG } \\
\text { HOLDIN, NUERNBERGER BET.-AG }\end{array}$ & 0.091 & 0.380 \\
\hline $2^{\text {nd }}$ club & SAMPO OYJ, GENERALI DEUTSCH & 1.746 & 5.724 \\
\hline $\begin{array}{l}\text { Non } \\
\text { converging }\end{array}$ & $\begin{array}{l}\text { UNIQA, AGEAS, TOPDANMARK AS, CNP } \\
\text { ASSURANCES, SCOR SE, ALLIANZ SE, HANNOVER } \\
\text { RUECKVERSIC, MUNCHENER RUCKVER }\end{array}$ & -0.583 & -43.294 \\
\hline
\end{tabular}




\section{Macrothink}

With regards to Growth Rate of Real Total Assets three clubs exist with 3, 2 and 2 insurers, respectively (Table 7 ). The first club converges at a higher speed $(\widehat{b}=0.670)$ than the remaining two clubs $(\widehat{b}=0.025)$ and $(\widehat{b}=-0.961)$ that weakly converge. The first cluster consists of Vienna Insurance, ALM Brand and Wuerttembergische; the second cluster of Sampo Oyj and Nuernberger Bet; the third cluster of AXA and Generalli Deutsch. Finally, the remaining insurers diverge as shown by the log t-statistic.

Table 7. Growth rate of real total assets

\begin{tabular}{|l|l|l|l|}
\hline & Firms & b coefficient & t-statistic \\
\hline Full sample & & -1.121 & -8.116 \\
\hline $\mathbf{1}^{\text {st }} \mathbf{c l u b}$ & $\begin{array}{l}\text { VIENNA INSURANCE, ALM BRAND AS, } \\
\text { WUERTTEMBERGISCHE LE }\end{array}$ & 0.670 & 0.886 \\
\hline $\mathbf{2}^{\text {nd }} \mathbf{c l u b}$ & SAMPO OYJ, NUERNBERGER BET.-AG & 0.025 & 0.087 \\
\hline $\mathbf{3}^{\text {rd }} \mathbf{c l u b}$ & AXA, GENERALI DEUTSCH & -0.961 & -0.807 \\
\hline \multirow{2}{*}{$\begin{array}{l}\text { Non } \\
\text { converging }\end{array}$} & $\begin{array}{l}\text { ANIQA, AGEAS, TOPDANMARK A/S, CNP } \\
\text { HANNOVER RUECKVERSIC, MANNHEIMER AG } \\
\text { HOLDIN, MUNCHENER RUCKVER }\end{array}$ & -0.682 & -41.189 \\
\hline
\end{tabular}

In terms of the Total Expenses to Assets ratio, two sub-clubs are highlighted with 4 and 2 insurers, respectively (Table 8). The first club consists of Vienna Insurance, ALM Brand, Wuerttembersgische and Generalli Deutsch and converges at a higher speed than the second club which is made up by AXA and Nuerneberget Bet. All the other insurers diverge according the $\log$ t-statistic, which rejects the null hypothesis of convergence at $1 \%$ significant level. 
Table 8. Total expenses to assets

\begin{tabular}{|c|c|c|c|}
\hline & Firms & b coefficient & t-statistic \\
\hline Full sample & & -0.878 & -284.941 \\
\hline $1^{\text {st }}$ club & $\begin{array}{l}\text { VIENNA INSURANCE, ALM BRAND AS, } \\
\text { WUERTTEMBERGISCHE LE, GENERALI } \\
\text { DEUTSCH }\end{array}$ & 0.485 & 5.589 \\
\hline $2^{\text {nd }}$ club & AXA, NUERNBERGER BET.-AG & 0.321 & 0.154 \\
\hline $\begin{array}{l}\text { Non } \\
\text { converging }\end{array}$ & $\begin{array}{l}\text { UNIQA, AGEAS, TOPDANMARK A/S, SAMPO OYJ, } \\
\text { CNP ASSURANCES, SCOR SE, ALLIANZ SE, } \\
\text { HANNOVER RUECKVERSIC, MANNHEIMER AG } \\
\text { HOLDIN, MUNCHENER RUCKVER }\end{array}$ & -0.934 & -190.823 \\
\hline
\end{tabular}

The final ratio to be examined is the Total Reserves to Assets and the club convergence algorithm reveals two sub-clubs (Table 9). The first is comprised by Vienna Insurance, ALM Brand and Wuerttembergische and second by Sampo Oyj, Generalli Deutsch Mannheimer and Nuerneberger. The convergence coefficient reveals that the second cluster converges at a higher speed $(\widehat{b}=0.610)$ compared with the first cluster $(\widehat{b}=0.270)$. Finally, the remaining insurers diverge.

Table 9. Total reserves to assets

\begin{tabular}{|c|c|c|c|}
\hline & Firms & b coefficient & t-stat \\
\hline Full sample & & -1.046 & -19.134 \\
\hline $1^{\text {s }}$ club & $\begin{array}{l}\text { VIENNA INSURANCE, ALM BRAND AS, } \\
\text { WUERTTEMBERGISCHE LE }\end{array}$ & 0.270 & 0.655 \\
\hline $2^{\text {nd }}$ club & $\begin{array}{l}\text { SAMPO OYJ, } \text { GENERALI DEUTSCH, } \\
\text { MANNHEIMER AG HOLDIN, NUERNBERGER } \\
\text { BET.-AG }\end{array}$ & 0.610 & 1.269 \\
\hline Non-converging & $\begin{array}{l}\text { UNIQA, AGEAS, TOPDANMARK A/S, CNP } \\
\text { ASSURANCES, AXA, SCOR SE, ALLIANZ SE, } \\
\text { HANNOVER RUECKVERSIC, MUNCHENER } \\
\text { RUCKVER }\end{array}$ & -0.357 & -45.994 \\
\hline
\end{tabular}

\section{Conclusions}

The results presented in this paper represent only a first step towards understanding the factors behind long-term integration in the insurance sector. First, it calls into question the 
role of harmonization and regulation across the EMU as a force leading to the creation of common market. These rules are typically amended before their implementation at the national level. In the face of imperfect integration in real and financial markets, it may be argued that this implementation process is adapted to the existing practices and preferences of local insurance businesses, thus providing a further incentive towards divergence in the long run. Second, it is not clear whether a mere change in the structure of projective costs is a factor strong enough to change the preferences of insurances in the implementation of their strategic plans of development. In particular, financial firms may have different instruments to neutralize the impact of common regulatory regimes.

The results have helpful implications for the insurance industry by helping to identify the need for certain functions undertaken by the insurers in terms of underwriting and risk selection, pricing, and liability management. They could also be useful to identify the way securitization is expected to mitigate any negative effect on liquidity and leverage, to enhance credit quality considerations, to improve any regulatory considerations, to facilitate more efficient risk management, and, thus, to permit the participating insurance firms to continue their growth.

Our results can be extended along a number of relevant directions. It would be interesting to understand how far the speed of convergence differs between clusters of financial firms, on average. Understanding the relation between the convergence rates and observable economic and financial variables, such as money market rates and measures of macroeconomic performance, would provide additional insights on the nature of the different convergence clubs. Finally, it would be important to measure the persistence of the deviations from long-term convergence levels across other financial institutions, such as banks.

\section{Acknowledgement}

The authors wish to to thank the Editor and a referee of this journal for their constructive comments and suggestions on an earlier draft of this paper. Needless to say, the usual disclaimer applies.

\section{References}

Adam K., Jappelli T., Menichini A., Padula M., \& Pagano M. (2002). Analyse, Compare and Apply Alternative Indicators and Monitoring Methodologies to Measure the Evolution of Capital Market Integration in the European Union, Working Paper, Center for Studies in Economics and Finance, University of Salerno.

Affinito M., \& Farabullini F. (2006). Does the Law of One Price Hold in Retail Banking? An Analysis of National Interest Rate Differentials in the Euro Area, Research Paper, Bank of Italy, Economic Research Department, http://www.ijcb.org/journal/ijcb09q1a1.pdf

Baele, L., Ferrando, A., Hoerdahl, P., Krylova, E., \& Monnet, C. (2004). Measuring Financial Integration in the Euro Area. Occasional Paper Series, 14, European Central Bank.

Barro, R. J., \& Sala-i-Martin, X. (1991). Convergence Across States and Regions. Brookings Papers on Economic Activity, 22, 107-182. http://dx.doi.org/10.2307/2534639 
Barro, R. J., \& Sala-i-Martin, X. (1992). Convergence, The Journal of Political Economy, 100, 223-251. http://dx.doi.org/10.1086/261816

Bekaert, G., \& Harvey, C. R. (1995). Time-Varying World Market Integration. Journal of Finance, 50, 403-444.

Bekaert, G., \& Harvey, C. R. (1997). Emerging Equity Market Volatility. Journal of Financial Economics, 43, 29-77. http://dx.doi.org/10.1016/S0304-405X(96)00889-6

Campbell, J. Y., \& Shiller, R. J. (1988). Stock Price, Earnings and Expected Dividends. Journal of Finance, 43, 661-676.

Campbell, J. Y., \& Shiller, R. J. (1989). The Dividend-Price Ratio and Expectations of Future Dividends and Discount Factors. Review of Financial Studies, 1, 195-228. http://dx.doi.org/10.1093/rfs/1.3.195

Campbell, J. Y., \& Shiller, R. J. (2005). Valuation Ratios and the Long-Run Stock Market Outlook: An Update, Chapter 5 in Richard H. Thaler (ed.), Advances in Behavioral Finance, II, Princeton University Press, 173-201.

Caporale, G., M., Erdogan, B., \& Kuzin, V. (2009). Testing for Convergence in Stock Markets: A Non-Linear Factor Approach. Working Paper, No. 09-35, Brunel University, http://www.brunel.ac.uk/_data/assets/pdf_file/0003/82128/0935.pdf

Cochrane, J. H. (1992). Explaining the Variance of Price-Dividend Ratios. Review of Financial Studies, 5, 243-280. http://dx.doi.org/10.1093/rfs/5.2.243

Cochrane, J. H. (1994). Permanent and Transitory Components of GNP and Stock Prices. Quarterly Journal of Economics, 109, 241-265. http://dx.doi.org/10.2307/2118434

Cochrane, J. H. (2001). Asset Pricing, Princeton University Press.

Cochrane, J. H. (2008). The Dog That Did Not Bark: A Defense of Return Predictability. Review of Financial Studies, 21, 1533-1575. http://dx.doi.org/10.1093/rfs/hhm046

Cummins, J. D. (2005). Convergence in Wholesale Financial Services: Reinsurance and Investment Banking. The Geneva Papers, 30, 187-222. http://dx.doi.org/10.1057/palgrave.gpp.2510031

Cummins, J. D., \& Weiss, M. A. (2009). Convergence of Insurance and Financial Markets: Hybrid and Securitized Risk-Transfer Solutions. The Journal of Risk and Insurance, 76, 493-545. http://dx.doi.org/10.1111/j.1539-6975.2009.01311.x

Cummins, J. D., Lalonde, D., \& Phillips, R. D. (2004). The Basis Risk of Index-Linked Catastrophic Loss Securities. Journal of Financial Economics, 71, 77-111. http://dx.doi.org/10.1016/S0304-405X(03)00172-7

Fabozzi, J., \& Choundhry, M. (2004). The Handbook of European Structured Financial Products. Wiley. 
Fama, E. F., \& K. R. French (1988). Dividend Yields and Expected Stock Returns. Journal of Financial Economics, 22, 3-27. http://dx.doi.org/10.1016/0304-405X(88)90020-7

Ferreira M. A. and Gama, P. M. (2005). Have World, Country and Industry Risk Changed Over Time? An Investigation of the Developed Stock Markets Volatility. Journal of Financial and Quantitative Analysis, 40, 195-222. http://dx.doi.org/10.1017/S0022109000001794

Ferreira M. A., \& Ferreira, M. A. (2006). The Importance of Industry and Country Effects in the EMU Equity Markets. European Financial Management, 12, 341-373. http://dx.doi.org/10.1111/j.1354-7798.2006.00324.x

Fratzscher, M. (2002). Financial Market Integration in Europe: On the Effects of EMU on Stock Markets. International Journal of Finance and Economics, 7, 165-93. http://dx.doi.org/10.1002/ijfe.187

Fritsche, U., \& Kuzin, V. (2008). Analysing Convergence in Europe Using a Nonlinear Single Factor Model, Macroeconomics and Finance Series, 200802, Hamburg University, Department Wirtschaft und Politik.

Goetzman, W. N. and Jorion, P. (1993). Testing the Predictive Power of Dividend Yields. Journal of Finance, 48, 663-679.

Hardouvelis, G. A., Malliaropulos, D., \& Priestley, R. (2007). The Impact of EMU on the Equity Cost of Capital. Journal of International Money and Finance, 26, 305-327. http://dx.doi.org/10.1016/i.jimonfin.2006.12.002

Hardouvelis, G., Malliaropulos, D., \& Priestley, R. (2004). EMU and European Stock Market Integration. Journal of Business, 79, 365-392. http://dx.doi.org/10.1086/497414

Hecht, P., \& Vuolteenaho, T. (2006). Explaining Returns with Cash-Flows Proxies. Review of Financial Studies, 19, 159-194. http://dx.doi.org/10.1093/rfs/hhj001

Hodrick, R. (1992). Dividend Yields and Expected Stock Returns: Alternative Procedures for Inference and Measurement. Review of Financial Studies, 5, 357-386. http://dx.doi.org/10.1093/rfs/5.3.357

Islam, N. (2003). What have We Learnt from the Convergence Debate? Journal of Economic Surveys, 17, 309-362. http://dx.doi.org/10.1111/1467-6419.00197

Lane, P., R. (2008). EMU and Financial Integration, The Euro at Ten: 5th European Central Banking Conference, Lucrezia Reichlin, Ed., ECB. IIIS 272. http://openaccess.city.ac.uk/1116/1/Gabrielsen,_Alexandros.pdf

Lettau, M. and Ludvigson, S. C. (2005). Expected Returns and Expected Dividend Growth. Journal of Financial Economics, 58, 58-626. http://dx.doi.org/10.1016/j.jfineco.2004.05.008

Lettau, M., \& Van Nieuwerburgh, S. (2008). Reconciling the Return Predictability Evidence. Review of Financial Studies, 21, 1607-1652. http://dx.doi.org/10.1093/rfs/hhm074 


\section{Macrothink}

Lewellen, J. W. (2004). Predicting Returns with Financial Ratios. Journal of Financial Economics, 74, 209-235. http://dx.doi.org/10.1016/j.jfineco.2002.11.002

Ozcan, K., S., Manganelli, S., Papaioannou, E., \& Peydró, J. L. (2009). Financial Integration and Risk Sharing: The Role of Monetary Union, The Euro at Ten: 5th European Central Banking Conference 13-14 November 2008, Lucrezia Reichlin, Editor.

Phillips, P. C., \& Sul, D. (2007). Transition Modelling and Econometric Convergence Tests. Econometrica, 75, 1771-1855. http://dx.doi.org/10.1111/j.1468-0262.2007.00811.x

Pontiff, J., \& Schall, L. D. (1998). Book-to-Market Ratios as Predictors of Market Returns. Journal of Financial Economics, 49, 141-160. http://dx.doi.org/10.1016/S0304-405X(98)00020-8

Quah D. (1996). Empirics for Economic Growth and Convergence. European Economic Review, 40, 1353-1376. http://dx.doi.org/10.1016/0014-2921(95)00051-8

Rozeff, M. S. (1984). Dividend Yields are Equity Risk Premia. Journal of Portfolio Management, 49, 141-160.

Rughoo, A., \& Sarantis, N. (2009). Integration in European Retail Banking: Evidence from Savings and Lending Rates to Non-Financial Corporations, Working Paper Series: 23-11, London metropolitan Business School, London Metropolitan University, http://www.londonmet.ac.uk/fms/MRSite/acad/lmbs/RESEARCH\%20CENTRES/CEMEA/ Working\%20Papers\%202011/23_2011.pdf

Sorensen, C. K., \& Guiterrez, J. M. P. (2006). Euro Area Banking Sector Integration - Using Hierarchical Cluster Analysis Techniques. ECB Working Paper, No. 627, 